\title{
Differences on self-perception of organizational pride and loyalty in Millennial \& Generation $X$, considering gender and seniority variables
}

\author{
Florina Guadalupe Arredondo Trapero ${ }^{1}$, Lida Esperanza Villa Castaño², \\ José Carlos Vázquez Parra ${ }^{3}$, Jorge De la Garza García ${ }^{4}$ \\ ${ }^{1}$ Ethics \& Philosophy Academic Department, Tecnologico de Monterrey, Mexico \\ 2 Pontificia Universidad Javeriana in Bogotá, Colombia \\ ${ }^{3}$ Department of Humanistic Studies, Tecnologico de Monterrey, Mexico \\ ${ }^{4}$ Marketing \& International Business Academic Department, Tecnologico de Monterrey, Mexico \\ corresponding e-mail: jcvazquezp[at]itesm(dot)mx \\ address: Tecnologico de Monterrey, Campus Guadalajara, Av. General Ramón Corona 2514, \\ Nuevo México, 45201 Zapopan, Jalisco, México.
}

\begin{abstract}
:
The research objective is to compare the differences in self-perception of organizational pride and loyalty between millennials and generation $x$, considering the variables of gender and seniority. The reason for this study is the importance of millennials' influence in the business sector, and the effect it is having in terms of turnover toward companies.

The study was conducted on 432 employees working in a cluster of companies located in northeastern Mexico. For statistical purposes, an analysis of variance (ANOVA) was performed on the different groups compared. Based on the findings, there is a generational difference in terms of organizational loyalty between male millennials and generation $x$ males, when both have recently joined their respective organizations. The differences withdraw when both groups have stayed more than 3 years at their organization. On the other hand, there are no variances between millennial men and millennial women, independently if they just arrived to the organization or have more than 3 years tenure working for their company. This reaffirms the existing similarities amongst millennials, specifically in the way this generation thinks about organizational culture, where there is no gender distinction.
\end{abstract}

JEL Classifications: M51, M54

Keywords: Millennial generation, organizational loyalty, organizational pride

Citation: Arredondo-Trapero, F.G., Villa-Castaño, L.E., Vázquez-Parra, J.C., De la Garza García, J. (2017). Differences on self-perception of organizational pride and loyalty in Millennial \& Generation $X$, considering gender and seniority variables. Business and Economic Horizons, 13(2), 270-286, http://dx.doi.org/10.15208/beh.2017.20

\section{Introduction}

The way in which millennials conduct themselves in the workplace may be due to their lack of experience and their high expectations, but there are specific values that define them as a unique generation. The different approaches to the study of millennials within the corporate world are diverse and contradictory. An empirical approach in a Latin American setting is demanded since there are not enough studies with reference to millennials in the workplace. In Mexico, the job turnover rate within the business sector, in regards to the millennial generation, is $15.7 \%$ (Anguiano, 2013). Millennials are setting the pace in terms of the management of human capital. Within a few years they will be a fully integrated at all corporate level, which means understanding that their retention strategies will become a priority. This implies that there is a need to study certain 
characteristics such as generation, gender, and how seniority in the company may influence their values, and therefore their behavior. The research objective is to compare the differences in self-perception of organizational pride and loyalty between millennials and generation $\mathrm{x}$, considering the variables of gender and seniority. This study is justified by the importance of millennials' influence in the business sector, and the effect on labor turnover.

Campione (2015) contends that retaining millennials is certainly a new challenge for managers. Once a company has hired a millennial, the next long-term goal for the organization is employee retention. Considering the new organizational context, loyalty and pride are two important cultural variables when seeking to retain a millennial employee. Millennials have no interest in being told about a professional career, as they do not expect to work in the same place throughout their lives. Millennials expect a fair salary in accordance with their performance, but they do not want to pay the price for achieving organizational profits. For instance, Kirk (2006) reports that job offers targeting millennials should emphasize the skills they will learn at work. Also, they look for frequent feedback, new opportunities at work, and skills development as much as possible.

According to Ferri-Reed (2014), 73.5\% of managers are concerned about how to retain millennials. In the past, when there was a shortage of jobs, it was easier to hold on employees. If a baby boomer wanted a job, she/he had to accept the job market conditions. Today, millennials look constantly for new job offers, and they readily accept them. The probability of changing their job a year after being hired is very high.

In response to these job market trends, the recruitment strategies for millennials have been reconsidered. Companies need to focus on work-family balance and flexibility at work. If these variables are addressed, an organization will be able to retain those millennials that are satisfied with their jobs (Twenge, 2010).

According to Ferri-Reed (2014), managers seeking to retain millennials should offer them the chance to grow within the organization, as well as identify and fulfill their expectations. It is not enough to inform millennials what the company has planned for them without knowing what they are interested in. It may be useful for top management to have an internal strategy to enable millennials to learn about the company's different business units, and thus enable them to better decide upon the career path they would like to take within the organization. Management may also design intergenerational teams so that millennials can understand how previous generations worked, as well as to share their own work styles.

Besides exploring new incentives, employers should also review their business practices and company policies to account for such low retention levels. In spite of the compensation strategies and employment policies for this generation, there is still a low level of retention among these employees. The benefits being offered by companies, in comparison to their extensive effort to invest their time in the recruitment process which includes hiring, training, and onboarding, are simply not enough to keep millennials in their current jobs.

Employers, who think they have undergone a successful onboarding and recruitment process, quickly discover that the young people they hired have either resigned or have been discharged from their employment. The average length of service is three years. Low productivity, absenteeism, low morale, and a high turnover rate undoubtedly pose a challenge for management. Millennials need to adapt and negotiate their roles in the organization and acclimate to the type of assessment performed by their peers and supervisors (Campione, 2015).

According to Rawlins, Indvik, \& Johnson (2008) since the beginning of the $21^{\text {st }}$ century employers have begun to realize that new recruits are different to their predecessors. They do not seem to be interested in the same things or be motivated by the same rewards as previous generations of working people. These observations have given rise to an endless 
number of studies that have focused on identifying the core traits of this new generation of millennials.

Gorman, Nelson, \& Glassman (2004) establish that there is no consensus on the start date for this generation. The proposed dates range from 1977 through to 1982. Nevertheless, Alexander \& Sysko (2012) contend that millennials first emerged as a generation between 1982 and 2009, which means they are now beginning to join the labor market.

The generation of baby boomers grew up thinking that loyalty and an obsession for workplace competence were rewarded with positions of leadership. They were raised at a time when both the economy and education system were thriving, which made them think they had to capitalize on hard work to deserve their achievements (Rosa, Cunha, \& Souza, 2012). Nevertheless, baby boomers continued to work, not only to cover their financial needs but also as a way of finding personal meaning. The need to remain active, along with the option of flexible working hours, has allowed baby boomers to continue working even after they have retired. This implies there is a certain intergenerational convergence between baby boomers, generation $\mathrm{x}$ and generation $\mathrm{y}$, or millennials.

In the generational transition, both baby boomers and generation $\mathrm{x}$ come into conflict and confrontation with millennial employees, who demand a series of benefits and adjustments by the organization. The previous generations were considered good soldiers; they followed their superiors' directives, and upheld a strict top-down chain of command. They were provided with the information needed for decision-making (Ferri-Reed, 2014).

Regarding millennials at work, Twenge (2010) conceives that understanding the generational change is particularly important in the light of the mass retirement of baby boomers, and their replacement by millennials, whose arrival in the labor market has revealed both the positive and negative aspects of this generation. Most of their characteristics are reflected in their millennial values, socialized during their childhood; it is relevant to consider this aspect in order to try to identify how they develop in an organizational setting.

\section{Millennials and their cultural values}

When trying to analyze the values that define this generation, it is difficult to distinguish between millennials' behavior due to their youth, and the typical behavior of the generation to which they belong.

In terms of empirical research purposes, it is difficult to study the generational traits of millennials. This requires longitudinal studies that allow separating the age variable from the generation variable (Campione, 2015). Nevertheless, although there is a lack of longitudinal studies, both positive and negative descriptions have been forthcoming on millennials' values both during their upbringing and as expressed in the workplace.

Before defining the traits that characterize millennials within the workplace, and to better understand this generation, we need to find out how their personal ethics were formed, and what socio-cultural values permeate through them.

Millennials grew up in a world in which there were no losers; they were all considered winners. This has meant they do not want to wait for years until they are promoted. They are constantly on the lookout for opportunities for professional development that will take them up to the next organizational level as quickly as possible. Likewise, they are not prepared to sacrifice themselves for their work. They look for jobs that provide flexible working hours and more time for rest and relaxation (Vitorio \& Lopes, 2012).

Morrow (2008) reports that most millennials had parents who were devoted to their children, who sought to praise them in everything, including activities that were used to forge a sense of competence. Their unrealistic expectations have made it difficult for them to understand that one does not always win, and that hard work may sometimes end up in 
failure. The upbringing that millennials have been given by their parents has deprived them of a sense of independence and responsibility, which is reflected in their aversion to and fear of ambiguity (Pacheco \& Castellá, 2012).

Alexander \& Sysko (2012) have provided statistical evidence on how these variables of parental upbringing have shaped the way millennials are today. They also refer to the interest in having "me-time", even forgetting one's friends and focusing solely on the achievement of personal goals.

Gorman, Nelson, \& Glassman (2004) contend that according to various studies some of the traits that distinguish millennials from Generation $\mathrm{X}$ are as follows: they are cleverer, they have better communication skills, and they work together while gathering information quickly and sharing it with the same efficiency. They respect diversity and multiculturalism, and they are resilient; they are comfortable in conversing and do so freely on an intellectual level. Their opinions are highly valued, given that age is not an important factor. It is said, furthermore, that this is the generation that has received the most attention, so they find it a challenge to perform in an unsupervised environment.

Finally, other cultural traits are mentioned by Bucic, Harris, \& Arli (2012), whereby millennials tend to be receptive to ethical issues. They value multiculturalism, and they express social, cultural and environmental awareness. They are loyal to their families and friends, as well as to themselves, as a replacement for being loyal to corporations (Hira, 2007). In summary, cultural values are relevant to understand millennial attitudes and how theirvalues are particularly reflected in the workplace.

\section{Millennials' values at the workplace}

Understanding millennials requires understanding their values related to work, attitudes and personality traits. It is important to understand how these impact upon their ability to learn, their personal expectations about society and organizations, as well as the approach to negotiate their roles at work, and their evaluation by colleagues and supervisors.

Hedonism and narcissism, which did not previously feature in corporate culture, are now said to characterize millennials; with the claim that this generation has inappropriate work habits, such as a lack of initiative, unrealistic expectations, and a lack of respect for authority (Ferri-Reed, 2014).

Myers \& Sadaghiani (2010) argue that several stereotypes have been generated regarding millennials, which contain both negative and positive characteristics. The negative ones include the consideration that this generation lacks motivation, is self-centered, disrespectful and disloyal, even devoid of ethics.

According to Campione (2015), millennials are not well prepared for the reality and stress of a working environment. The skills that baby boomers have to survive and fight for their position in the workplace, have not been passed on to millennials, which might explain why the latter are so quick to move to another organization.

Based on Campione (2015) such attitudes shown by millennials may reveal the main issue. Baby boomers paid a high personal price through long working hours and difficult labor conditions in return for the rewards they received from their careers. Empirical studies conducted on this generation have found that they focused on competition and on climbing the corporate ladder. Although baby boomers did not look favorably upon such practices, they stoically accepted them as part of the status quo within the organization. Millennials have noted these effects, and this may be one of the reasons that have led millennials to question the price and meaning of money, status, and respect, and the cost for them, their family and society.

In spite of those traits of millennials that are open to criticism, this same generation is also loyal to its superiors (although not to the corporations themselves), with an idealistic commitment to both vision and values. They may prove to their employer that they have 
the capacity for hard work in exchange for immediate reward and recognition. In addition, they are willing to collaborate very closely, and they have a huge amount of selfconfidence, which means they provide the working environment with considerable dynamism (Ferri-Reed, 2014).

This generation attributes less importance to work and more to the enjoyment of life than generation X. However contrary to popular belief, social values are equally important to millennials, and previous generation (Poleto, Lochins, \& Sirangelo, 2015).

According to Myers \& Sadaghiani (2010), millennials have also been attributed positive traits. These qualities are teamwork, motivation to have an impact on the organization, open and fluid communication with supervisors and the ease with which they handle advanced communication technology. Within this context, do Nascimento-João et al. (2015) have identified three factors that define millennials: networking, work/pleasure, and sustainability/environment.

Nonetheless, millennials have refused to accept the traditional practices of the workplace, such as being treated badly by employers, a lack of supervision and guidance, and a lack of meaning at work. Millennials are undoubtedly redefining the ethics of work. Considering that work has little value in their lives, instead millennials try to enjoy and find their place in life.

According to Kirk (2006), millennials may be considered an optimistic generation with great expectations of success. However, they are not good at making long-term plans that enable them to realize their dreams. It is a more individualistic generation that has created its own definition of success (Leandro, Giardini, Negreiros, Pedralho, \& Carvalhedo, 2013). They are willing to work hard to finish the job, wherever and whenever. They are also interested in seeing how their effort benefits them in the short term, and how it contributes in a broader perspective of their lives.

Ng, Schweitzer, \& Lyons (2010) explain that millennials emphasize the social aspects of work. They also seek to cooperate closely and learn from their peers and managers, who they respect and with whom they expect to forge a friendship. The quality of managers was the second motivational factor identified in them. An influence on this appraisal is the fact that the manager is available to provide them with feedback.

Specifically, Jayson (2007) has found that millennials are identified by such concepts as loyalty, enrichment, fulfilling their peers' expectations, a thirst for fame, being the breadwinner for a modest family and having a comfortable lifestyle. Along these same lines, Nations (2007) has defined millennials as having a strong desire for "me-time", personal growth, security, a desire for intrinsic recognition, and opportunities for leadership and team development.

Campione (2015) studies millennials' attitudes in the workplace, their values, their personality traits, their response to corporate offers, employment policies, and employers' approaches to their job satisfaction. The findings reveal that there is a moderate impact on millennials related to the payment they receive, their retirement pension, flexible schedule, and the support of colleagues. There is a negative impact on millennials concerning overtime or irregular work schedules. Furthermore, regarding their work ethics, millennials have little interest in hard work, or extra shifts (Smola \& Sutton, 2002).

According to Ng, Schweitzer, \& Lyons (2010), pay is one of the main motivational factors for millennials, as in a certain way it reflects how well they are doing their jobs; salaries serve as feedback to measure their performance. On the other hand, their impatience for success means that they look for instant rewards, instead of having to pay the price for them. When they do not see a swift reward, a millennial will look for another job. Although promotions are very important for millennials, they want them with the least effort, and perhaps this reflects a certain sense of entitlement.

In relation to the above, $\mathrm{Ng}$, Schweitzer, \& Lyons (2010) state that millennials are impatient for success, have high wage expectations, and do not believe promotion should 
be linked to performance. There is a relative narcissism in their feeling of having certain rights. Furthermore, millennials place special emphasis on socializing at work, so they expect to have good colleagues and bosses. Finally, in keeping with their ideas of changing the world, millennials have high expectations of corporate social responsibility (CSR) and organizational ethics. Even though millennial's work ethics is changing the meaning of work, there is a fundamental idea behind the way they think about their life in every aspect: individualism.

\section{Millennials' individualism in the workplace}

Millennials focus on their individual goals and personal success, which reflects a life-style, instead of a professional career. The generational studies conducted on millennials have found positive individual traits such as self-esteem and assertiveness. Such traits lead to the demand for the right to be successful and contribute to the working environment regardless of their background, as the individual is what really matters, not the group of reference. Nevertheless, they also have traits that involve impatience and a lack of perseverance.

These individualist traits related to narcissism induce in them a sense of entitlement (of having the right); so they project a constant need for recognition, risk aversion, and an inability to deal with ambiguity. This leads them to require specific rubrics for their job, well defined expectations, and continuous feedback from their supervisors (Myers \& Sadaghiani, 2010).

Henrie \& Taylor (2009) affirm that in terms of their working environment, millennials are more satisfied and have a greater need for job security, with a further highlight being the fact that they experience greater satisfaction based on recognition, advancement, and their professional career. Also their rate of intended turnover is no different from that of previous generations (Twenge, 2010).

Finally, Ng, Schweitzer, \& Lyons (2010) indicate that millennials give great significance to individualistic aspects of their work. Although they may have realistic expectations about their job and salary, they also expect to advance in their professional career and to master new skills. At the same time, they are looking for a meaningful and satisfactory life, outside the workplace. Even though individualism is an important characteristic for millennials, the technological change increases this personality trait.

\section{Millennials and technological competence}

This generation has an intense relationship with technology (Ferri-Reed, 2014), being referred to as digital natives. Diverse studies have analyzed how this generation is using and applying ICTs (Information \& Communication Technology), as in the case of the critical analysis conducted by Marciales-Vivas \& Cabra-Torres (2009). Although other generations may be technologically competent, they are considered to be digital immigrants (Hershatter \& Epstein, 2010). Yet it is not simply a question of identifying groups by their use of technology, but rather it is important to consider the way millennials have integrated technology into their lives, which indicates they have a special differentiation with previous generations. This is the first generation whose members consider themselves as proficient users of technology. For them, the use of technology is a natural experience in their lives (Gordon, 2006). Correia de Moura (2013) reports that millennials consider technology as a tool of social inclusion. Social relationships are also important for millennials. What has changed are the means they use to socialize and stay connected globally. In addition, Villegas Portero \& Labrador Ruiz de la Hermosa (2016) indicate that the implementation of technology among millennials for educational 
purposes involves gamification (applying digital game \& design techniques to non-game situations), which has helped students to assimilate industry roles more effectively.

Along these same lines, what makes this generation unique is the technological expertise that enables its members to network and share information (Howe \& Strauss, 2000). Furthermore, Gorman, Nelson, \& Glassman (2004) categorically state that technological competence gives them a special place. They effectively and quickly use digital networks without any problem whatsoever for a whole range of different tasks. This competence is the outcome of an intense experience with internet-based communications.

Hershatter \& Epstein (2010) suggest that millennials not only use technology to retrieve information quickly and easily, but that thanks to this technology they can also think and operate in a world without boundaries.

\section{Millennials' expectations regarding organizations}

Millennials now call for greater openness and transparency in terms of information; they want to know and ask about everything. They need to put all the information on the table to better understand the organization and its decision-making processes, instead of following the discretionary decisions made by others. According to Ferri-Reed (2014), millennials expect to have access to information with transparency. Transparency means that collaborators understand the organization's information and the decision-making process. Transparency in the organization implies open communication, involving employees in decisions, changes, and providing continuous feedback for performance enhancement.

Gilley et al. (2015) have found that when comparing three different generations: baby boomers, generation $\mathrm{X}$, and millennials, in the fields of management, millennials stand out for their interest in employee growth, development, and their sense of justice and fairness.

In addition, based on Levenson \& Joiner (2012), when searching for a job, millennials are concerned about CSR (Corporate Social Responsibility) practices, specifically in relation to environmental issues.

Accordingly, Ng, Schweitzer, \& Lyons (2010) millennials want a job that is meaningful and satisfying. Likewise, they expect a company's values and mission to be a higher priority than the profit motive of the bottom line. This makes CSR critical for millennials, as they look for corporate values that are compatible with their own. Furthermore, they are intolerant of work that poses no significant challenges, and often perform poorly in high-volume work with a lack of stimulus.

Finally, regarding organizational structure, Hershatter \& Epstein (2010) note that millennials expect flat or horizontal organizations, and they want to have direct access to top management. This creates tension in the organization, as when faced with a problem this generation ignores the hierarchical system and goes straight to the top level. As a result, this shift in organizational access, has established new work practices, in order to satisfy the expectations of millennials.

\section{Adapting work practices for millennials}

Beyond the stereotypes, there is a need to analyze how managers are dealing with millennials in the workplace. According to Ferry-Reed (2014), millennials are demanding new challenges, since managers need to find new management styles. Millennials want their relationship with management be based more on friendship than on authority, as in previous generations. This means that their personal treatment may sometimes be seen as a lack of respect. 
Although employing millennials may have its complications, there is a need to understand and adapt working practices to the approach that this new generation brings to the environment within organizations. For example, according to the study conducted by Ferri-Reed (2014), 70\% of managers have altered their management practices to manage millennials. Interviews with managers have revealed that this generation requires closer supervision. The need for such supervision is not because they make mistakes or are careless, but instead because they want continuous feedback, as well as more guidance and mentoring. Furthermore, a high percentage of the managers interviewed affirm that they maintain the same level of exigency regarding performance for both millennials and more experienced employees, and that the former's ability to respond to challenges is very high.

In regard to the perception of bosses, Hershatter \& Epstein (2010) argue that millennials seek to maintain close relationships with their boss. The underlying reason for this is that throughout their whole lives they have always been supported by someone. In fact, it is the first generation to have always had a mentor to guide them. This relationship of mentor (prior generations) and protégée (millennials) may constitute an interesting rapport between the two, as neither look upon each other as competitors.

Nolan (2015) suggests there is also a need to manage an internal branding that generates a sense of belonging and understanding of the organizational mission. Nevertheless, Peotter (2015) argues that the rules that work for one employee are not necessarily of use to another. It is an oversight to apply a single management style across the board, and operate using a one-size-fits all strategy. Today's workplace is a blend of cultures and generations, which infers that an effective leader needs to implement a constantly changing leadership style.

The above has contributed to the industry's concern over how communication with millennials impacts organizations, and how millennials' skills will affect other employees, particularly baby boomers, and generation X. There is a need to create functional working relationships across each generation, as well as improve their organizational performance.

Making the most of the individual skills developed by millennials requires organizations to amend their corporate rules and policies. The value system and ethical conduct that millennials bring to the table may improve a company's relationships and productivity. If millennials are not accepted by previous generations, they will end up being marginalized, which will lead to a loss of respect and credibility within the organization. There is compelling evidence indicating that a lack of formal communication in an organization ultimately impacts on job satisfaction. Once committed to a project, millennials tend to prove their added value to the company, and their interest in playing their part within an organization, which leads them to behave like prior generations.

There is no question that firms interested in retaining, and fully engaging their best employees, will need to cater to the employment preferences of new generations. Therefore, a strategy that works in all cases is not enough for today's organizations. For instance companies need to reassess their employment policies in relation to work-life balance, and attend to employees' needs by focusing on the phase each generation is at during each level in their career (Myers \& Sadaghiani, 2010).

\section{Work-life balance: a demand made by millennials}

The generation preceding millennials was negatively affected by social factors such as high divorce rates, low economic stability, and organizational cutbacks. The millennial generation now seeks to pursue a better work-family balance (Marston, 2007).

In correlation to the above argument, millennials have shown an interest in the reconciliation of work-family matters. Hence, they tend to look for jobs that provide flexible working hours, and a work-life balance that makes them better employees who experience more satisfaction in the workplace (Smith, 2010). 
This work priority has a generational explanation, viewing work as the focal point of one's life has been in decline over the generations. In the specific case of millennials, they are less focused on work, and more family oriented. For instance, the Families and Work Institute (2016) reports that recent years have seen a rise in the number of parents who say there is a conflict between their work and their family life. There has also been an increase in the option to work from home among both men and women; although for men the percentage increase has been higher. Finally, the Institute reports that working fathers have increased the time spent with their children from two to three hours per day over the period running from 1977 to 2008 . Working mothers have dedicated a stable 3.8 hours per day to their children over the same period of time (Families and Work Institute, 2008). In other words, the work-family balance is a major concern for new generations.

According to Hershatter \& Epstein (2010), millennials are conscious of the costs associated with lacking a suitable work-life balance, a high price which their parents paid in return for professional growth. Hence the reason for why millennials have a great desire to strike the right work-life balance, when they start in the workforce. On the other hand, Nolan (2015) states that one of their main complaints is the conflict between millennial's expectations for work-life balance, and what they perceive their managers think about this issue.

Based on Ng, Schweitzer, \& Lyons (2010), given that employers are struggling to attract and hire young talented employees, it is very important to understand the expectations of new hires, particularly when they join the labor force. The events to which millennials have been exposed have influenced the way they reevaluate their priorities in life, and choose jobs that permit them to prioritize their own lives. In view of this, they look for, and expect a work-life balance at each stage of their professional career.

\section{Millennials' behavior and questions about generation $\mathbf{x}$}

Gordon (2010) contends that the generation gap between millennials, and previous generations is not a question of age. A generation is defined by the way in which its members grow up experiencing their own unique understanding of the world. There are a series of events that the members of a specific generation share, which define its very nature. Ng, Schweitzer, \& Lyons (2010) propose that the events which have shaped millennials' lives include globalization, technological progress, and an increase in demographic diversity.

Considering the critics about millennials, for Hershatter \& Epstein (2010), millennials may not be a great generation, but they are definitely the next labor force, and if properly managed they have the potential to be a great one. From a different perspective, millennials' behavior will make previous generations question their own values. For example, previous generations will wonder whether the huge sacrifices they made at work have actually made them happy, or provided them with the rewards they expected. The values contributed by millennials will have a bearing on the search for a better work-life balance. On the other hand, managers will have to modify their discourse where being a "workaholic" is considered a good idea, and they will also have to avoid criticizing those who ask the company for a suitable work-life balance (Myers \& Sadaghiani, 2010). FerriReed (2014) reports that the process of "millennializing" an organization's internal climate not only involves attracting millennials but also how to increase their productivity, creativity and performance.

\section{Millennials as agents of change in organizations}

Hershatter \& Epstein (2010) explain that millennials' idealism makes them look upon themselves as agents of change. Their capacity for collaboration means they interpret 
problems as a way of advancing. In their view, social problems can be resolved through minor changes.

Ferri-Reed (2014) contends that employers need a new strategy that was previously focused on baby boomers, and now focus their concentration on millennials. Organizations with an advanced policy approach are implementing changes designed to attract and inspire millennials: communication within the workplace, social and technological media, corporate philanthropy, and the design of work spaces.

Although the natural aging process will undoubtedly change the way they think, millennials will leave their own generational mark with lasting changes. They are readier to accept diversity than prior generations, and they can see problems and opportunities from a more innovative perspective. In one way or another, millennials are acting as agents of change in organizations, and the effects of these changes will be demonstrated in the workplace. Although the view of millennials may be positive or negative, it is a fact that they are now working, and they constitute today's main workforce.

\section{Hypotheses}

Considering the theoretical framework, related to loyalty and pride for millennial and generation $\mathrm{x}$, the following hypotheses are established, (taking 3 variables: generation, gender, and seniority as criteria for comparisons):

H1: A female millennial has greater loyalty (a) and pride (b) toward the organization than a male millennial, considering that both have less than 3 years seniority.

H2: A female millennial has greater loyalty (a) and pride (b) toward the organization than a male millennial, considering that both have more than 3 years seniority.

H3: A female millennial has greater loyalty (a) and pride (b) toward the organization than a female generation $\mathrm{x}$, considering that both have less than 3 years seniority

H4: A female millennial has less loyalty (a) and pride (b) toward the organization than a generation $\mathrm{x}$ female, considering that both have more than 3 years seniority.

H5: A male millennial has greater loyalty (a) and pride (b) toward the organization than a generation $x$ male, considering that both have less than 3 years seniority.

H6: A male millennial has less loyalty (a) and pride (b) toward the organization than a generation $\mathrm{x}$ male, considering that both have more than 3 years seniority.

\section{Method}

The aim of this research is to identify statistical differences in terms of the self-perception of organizational pride and loyalty between millennials and generation $\mathrm{x}$ employees, considering the variables of gender and seniority in the company.

\section{Sample}

The study has involved 432 employees working in a business cluster in northeastern Mexico.

The following frequency tables show the distribution by gender (Table 1), by generation (Table 2), and by seniority in the organization (Table 3). In order to protect the participant anonymity, only the range of age and seniority were collected. 
TABLE 1. FREQUENCY BY GENDER

\begin{tabular}{lc}
\hline Gender & Frequency \\
\hline Female & 118 \\
\hline Male & 290 \\
\hline No answer & 24 \\
\hline Total & 432 \\
\hline
\end{tabular}

\section{TABLE 2. FREQUENCY BY GENERATION}

\begin{tabular}{lc}
\hline Seniority & Frequency \\
\hline Millennials & 144 \\
Aged 35 or under & \\
\hline Generation X & 272 \\
Aged over 35 & \\
\hline No answer & 16 \\
\hline Total & 432 \\
\hline
\end{tabular}

\section{TABLE 3. FREQUENCY BY SENIORITY}

\begin{tabular}{lc}
\hline Seniority & Frequency \\
\hline Fewer than 3 years & 165 \\
\hline More than 3 years & 244 \\
\hline No answer & 23 \\
\hline Total & 432 \\
\hline
\end{tabular}

In order to divide the sample in different groups by generation, gender and seniority, the following criteria were applied:

- The generation variable is divided into two subgroups: those under the age of 35 and those over the age of 35. Although, there is no precise date for the start of the millennial generation, for our purposes here we made the decision to apply an age cap of 35 for considering someone within this generational block.

- The gender variable was divided into males and females.

- The seniority variable was divided into subgroups of fewer than 3 years, and more than 3 years. It is assumed that someone with more than three years' seniority in the company has assimilated to the organizational culture, and will be more loyal to the organization.

\section{Questionnaire}

Organizational pride has been associated with the commitment to the company. Loyalty to the organization is related to actions that protect, defend and promote the reputation of the organization, both inside and outside the company (Podsakoff et al., 2000). According 
to the original questionnaire (designed and validated by Arredondo-Trapero, Rosas-Ferrer, Villa Castaño, 2011), the set of items for study of millennials' organizational pride and loyalty compared to generation $\mathrm{x}$ was formulated as follows:

\section{Loyalty to the organization (Cronbach Alpha 0.849)}

1. Outside of work, I usually express how valuable it is to work in this organization. (factor loading $=0.84$ )

2. Outside of work, I usually make favorable comments on the organization's corporate social responsibility projects. (factor loading $=0.76$ )

3. Outside of work, I usually encourage others to buy the products that the organization assembles / produces. (factor loading $=0.83$ )

\section{Organizational Pride (Cronbach Alpha 0.953)}

1. I am proud to tell others that I am part of this organization. (factor loading=0.92)

2. I refer to this institution to my friends as a great organization to work on. (factor loading $=0.91$ )

3. I am proud to work in this organization. (factor loading=0.91)

4. I am satisfied with the achievements of this organization. (factor loading=0.88)

5. I am proud of being identified with this organization. (factor loading $=0.82$ )

The scale used was 1 to 5 , whereby the higher the score, the greater the organizational pride and loyalty. For statistical purposes, an analysis of variance (ANOVA) has been conducted for comparing the different groups.

\section{Results and discussion}

Hypothesis H1 (a \& b) (see Table 4) on the organizational pride and loyalty in male and female millennials with little seniority is not proven. There are no significant differences in the sense of organizational pride and loyalty in millennials, whether they are male $(\mu$ pride $=4.00, \mu$ loyalty $=4.12)$ or female $(\mu$ pride $=4.33, \mu$ loyalty $=4.11)$ with little seniority. In other words, both male and female millennials that have recently joined the organization (less than 3 years) have the same level of organizational pride and loyalty.

Hypothesis H2 (a \& b) on the organizational pride and loyalty in male and female millennials with more seniority is not proven. There are no significant differences in the sense of organizational pride and loyalty in millennials with more seniority according to gender. We may therefore infer that both male (pride $\mu=4.23$, loyalty $\mu=4.30$ ) and female (pride $\mu=4.33$, loyalty $\mu=4.44$ ) millennials who have been employed by the organization for some time (more than 3 years) have the same level of organizational pride and loyalty.

Hypothesis H3 (a \& b), which tests the organizational pride and loyalty in female millennials and generation $x$ females with little seniority is not proven. There are no significant differences in the sense of pride and loyalty in female colleagues, bearing in mind they belong to different generations and both have little seniority in the organization. According to the study, both female millennials (pride $\mu=4.33$, loyalty $\mu=4.11$ ) and generation $\mathrm{x}$ (pride $\mu=4.23$, loyalty $\mu=4.38$ ) that have recently joined the organization (less than 3 years) have the same level of organizational pride and loyalty.

Hypothesis H4 (a \& b), which tests the organizational pride and loyalty in female millennials and generation $x$ females with more seniority is not proven. There are no significant differences in the sense of pride and loyalty in female colleagues, bearing in mind they belong to different generations and both have more seniority in the organization. Based on the statistical analysis, both the millennial (pride $\mu=4.33$, loyalty $\mu=4.44$ ) and generation $\mathrm{x}$ women (pride $\mu=4.04$, loyalty $\mu=4.14$ ) who have been working in the organization for some time (more than 3 years) have the same level of loyalty. 


\section{TABLE 4. HYPOTHESIS TEST}

\begin{tabular}{|c|c|c|}
\hline \multirow{3}{*}{$\begin{array}{l}\text { HYPOTHESIS } \\
\mathrm{H} 1(\mathrm{a}, \mathrm{b})\end{array}$} & MEAN & $\mathrm{P}$ VALUE $<.10$ \\
\hline & $\begin{array}{l}\text { Loyalty: } \\
\text { Female millennial } \mu: 4.11 \\
\text { Male millennial } \mu: 4.12\end{array}$ & Loyalty $p$ value: 0.975 \\
\hline & $\begin{array}{l}\text { Pride: } \\
\text { Female millennial } \mu: 4.33 \\
\text { Male millennial } \mu: 4.00\end{array}$ & Pride $p$ value: 0.133 \\
\hline \multirow[t]{2}{*}{$\mathrm{H} 2(\mathrm{a}, \mathrm{b})$} & $\begin{array}{l}\text { Loyalty: } \\
\text { Female millennial } \mu: 4.44 \\
\text { Male millennial } \mu: 4.30\end{array}$ & Loyalty $p$ value: 0.618 \\
\hline & $\begin{array}{l}\text { Pride: } \\
\text { Female millennial } \mu: 4.33 \\
\text { Male millennial } \mu: 4.23\end{array}$ & Pride $p$ value: 0.770 \\
\hline \multirow[t]{2}{*}{$\mathrm{H} 3(\mathrm{a}, \mathrm{b})$} & $\begin{array}{l}\text { Loyalty: } \\
\text { Female millennial } \mu: 4.11 \\
\text { Female generation } x \mu: 4.38\end{array}$ & Loyalty $p$ value: 0.302 \\
\hline & $\begin{array}{l}\text { Pride: } \\
\text { Female millennial } \mu: 4.33 \\
\text { Female generation } x \mu: 4.23\end{array}$ & Pride $p$ value: 0.669 \\
\hline \multirow[t]{2}{*}{$\mathrm{H} 4(\mathrm{a}, \mathrm{b})$} & $\begin{array}{l}\text { Loyalty: } \\
\text { Female millennial } \mu: 4.44 \\
\text { Female generation } x \mu: 4.14\end{array}$ & Loyalty $p$ value: 0.324 \\
\hline & $\begin{array}{l}\text { Pride: } \\
\text { Female millennial } \mu: 4.33 \\
\text { Female generation } x \mu: 4.04\end{array}$ & Pride $p$ value: 0.429 \\
\hline \multirow[t]{2}{*}{$\mathrm{H} 5(\mathrm{a}, \mathrm{b})$} & $\begin{array}{l}\text { Loyalty: } \\
\text { Male millennial } \mu: 4.12 \\
\text { Male generation } x \mu: 4.40\end{array}$ & Loyalty $p$ value: $0.079^{*}$ \\
\hline & $\begin{array}{l}\text { Pride: } \\
\text { Male millennial } \mu: 4.00 \\
\text { Male generation } x \mu: 4.17\end{array}$ & Pride $p$ value: 0.444 \\
\hline \multirow[t]{2}{*}{$\mathrm{H} 6(\mathrm{a}, \mathrm{b})$} & $\begin{array}{l}\text { Loyalty: } \\
\text { Male millennial } \mu: 4.30 \\
\text { Male generation } x \mu: 4.22\end{array}$ & Loyalty $p$ value: 0.682 \\
\hline & $\begin{array}{l}\text { Pride: } \\
\text { Male millennial } \mu: 4.23 \\
\text { Male generation } x \mu: 4.22\end{array}$ & Pride $p$ value: 0.948 \\
\hline
\end{tabular}

Hypothesis H5 (a \& b), which tests the organizational pride and loyalty in male millennials and generation $\mathrm{x}$ males with little seniority is partially proven. There are significant differences in the sense of loyalty, but not in terms of pride, among male colleagues bearing in mind they belong to different generations and both have little seniority in the organization. This leads us to infer that male millennials (loyalty $\mu=4.12$ ) with little seniority have a lower sense of organizational loyalty than their generation $\mathrm{x}$ (loyalty $\mu=4.40$ ) when both have recently joined the organization ((less than 3 years). Nevertheless, there is no difference for these two groups in terms of organizational pride (millennial pride $\mu=4.00$, generation $\times$ pride $\mu=4.17$ ).

Hypothesis H6 (a \& b), which tests the organizational pride and loyalty in male millennials and generation $\mathrm{x}$ males with more seniority is not proven. There are no significant differences in the sense of pride and loyalty in male colleagues, regardless of whether they are millennials or generation $\mathrm{x}$ with more seniority. In other words, both the millennial (pride $\mu=4.23$, loyalty $\mu=4.30$ ) and generation $\mathrm{x}$ men (pride $\mu=4.22$, loyalty $\mu=4.22$ ) who 
have been working in the organization for some time (more than 3 years) have the same level of organizational pride and loyalty.

Considering the results regarding organizational pride and loyalty toward the organization among employees (depending on gender, generation, and seniority), it may be contended that as males acquire more seniority in the company, they have a greater sense of loyalty, with no generational differences.

In the case of male and female millennials, they both have a similar level of organizational pride and loyalty, which are the lowest among the entire sample studied This evidence contradicts, at least for this generation, the argument over whether men and women differ in terms of moral reasoning. According to moral reasoning theories, men tend to think more about their own individual interests (Kohlberg, 1981), while women focus on the interests of the collective (Gilligan, 1982). This argument has been used to explain the finding, reported by Arredondo-Trapero, De la Garza-García, \& Villa-Castaño (2015), that there is a significant difference in attitudes toward collaboration among young employees, depending on whether they are male or female. Nevertheless, this does not hold in the case of organizational pride and loyalty, where there are no such differences.

A male or female millennial is equally likely to change jobs for a better salary, or they may be astute to consider that their long-term future does not lie within the organization. This study of the millennial generation in terms of gender reveals there are no differences in the way they embrace organizational pride and loyalty. Organizational pride and loyalty appears to reflect a way of thinking that corresponds more to the millennial generation itself than to issues of gender. Our finding supports what Hira (2007) and Myers \& Sadaghiani (2010) argue regarding millennials and their lack of loyalty and pride for the company.

Regarding millennials of both sexes, it is interesting to note that although they belong to this generation, as soon as they acquire more seniority within the company, there are no significant differences in terms of loyalty between them and the men and women that make up the previous generation. The reason may lie in the effect that this affiliation may have on the employee's assimilation of the organization's culture. This implies that an organization's culture transfers its values (e.g., loyalty and pride) in all collectives, men/women, and millennials/generation x employees, whereby there are no generational differences in terms of organizational pride and loyalty.

The only significant difference in terms of loyalty was found when comparing the male sample (millennials and generation $\mathrm{x}$ ). This difference arises only when both collectives have recently joined the company. The male millennials who have recently been hired by the company, are less loyal than generation $\mathrm{x}$ males in the same position (considering the items that were part of the questionnaire). They are significantly better disposed to leave their jobs, and not have to remain in the company for a long time. If another offer is better, they tend to swap one company for another, and refrain from making positive comments about the organization or the products it assembles/produces.

\section{Conclusion}

Based on the results of this research, which focuses on the self-perception of organizational pride and loyalty, we may affirm that there is indeed a generation gap in terms of loyalty between male millennials and the generation x males. Nevertheless, the organizational culture that permeates through over time has the same impact on male millennials and on previous generations, as these differences then disappear. Furthermore, there is no difference in organizational pride and loyalty between male and female millennials, as both have a similar self-perception, which questions whether the differences attributable to gender regarding the employee's attachment to the organization may be more of a generational nature. 
It is important for companies to implement strategies for instilling a business culture that is designed to retain talent in the form of recently recruited millennials, regardless of gender issues. This claim is based on the findings for this collective in terms of organizational pride and loyalty. Corporate human resources (HR) departments should consider that both male and female millennials have the same concerns regarding the exploration of job openings in other organizations. The high cost of job turnover involved in the continuous arrival and departure of millennials in organizations undoubtedly means that the retention of millennials continues to pose a challenge for companies.

Furthermore, HR managers would be required to focus on retention strategies that particularly target millennials, which in turn may be different to those strategies applied to generation x male employees, who have recently been hired. In other words, it needs to be understood that what works for one collective group, does not necessarily have the same impact on another. HR managers should have innovative and flexible strategies with technological backing for retaining talented millennials. This is a particular priority during an employee's first three years in the company.

One of the study's limitations is that the results on loyalty and pride that this research provides involve a specific cluster of manufacturing companies in northeastern Mexico. New research needs to be conducted on different business and organizational environments. There is no doubt that this generational change challenges former approaches to HR management, that justifies the need to study this topic in greater depth.

\section{References}

Alexander, C., Sysko, J. (2012). Study of the cognitive determinants of Generation Y's Entitlement Mentality. Academy of Educational Leadership Journal, 16(2), 63-68.

Anguiano, D. (2013). El periodismo necesita inversión. Milenio, available at: http://www.milenio.com/negocios/rotacion-personal-Mexico-alcanzaniveles_0_116988619.html (Accessed 27 December 2016).

Bell, E. (2008). Exploring employee perception of the work environment along generational lines. Performance Improvement, 47(9), 35-45.

Bucic, T., Harris, J., Arli, D. (2012). Ethical consumers among the millennials: A Cross-National Study. Journal of Business Ethics, 110, 113-131.

Campione, W. (2015). Corporate offerings: Why aren't millennials staying? Journal of Applied Business and Economics, 17(4), 60-74.

Correia de Moura, D; (2013). Abordagens no campo da comunicação e o contemporâneo da mobilidade: Jovens e o desafio smartphone. Razón y Palabra, 18, 36-42.

do Nascimento João, B.; Carvalho dos Santos Claro, J. A.; Prudêncio Tinoco, J.E.; de Oliveira Fernandes Torres, M.; (2015). Carrera, renta y consumo bajo la perspectiva del joven de la generación "Y".. Invenio, 18, 119-135.

Families and Work Institute (2016). Is your go-to work-life/workplace, available at: http://familiesandwork.org/downloads/GenderInfographic.pdf (Accessed 27 December 2016).

Families and Work Institute (2008). Times are changing. Gender and generation at work and at home, available at: http://familiesandwork.org/downloads/TimesAreChanging.pdf (Accessed 27 December 2016).

Ferri-Reed, J. (2014). Are Millennial employees changing how managers manage? The Journal for Quality and Participation, 37(2), 15-35.

Ferri-Reed, J. (2014). Millennializing the workplace. The Journal for Quality and Participation, 37(1), 1314.

Ferri-Reed, J. (2013). onboarding strategies to supercharge Millennial employees. The Journal for Quality and Participation, 36(2), 32-33. 
Gilley, A., Waddell, K., Hall, A., Avery, S., Gilley, J. W. (2015). Manager behavior, generation, and influence on work-life balance: An empirical investigation. The Journal of Applied Management and Entrepreneurship, 20(1), 3-23.

Gilligan, C. (1982). In a different voice: Psychological theory and women's development, Cambridge, MA: Harvard University Press.

Gordon, R.S. (2006), The NextGen librarian's survival guide, Information Today, Medford, NJ.

Gordon, S. (2010). Once you get them, how do you keep them? Millennial librarians at work. New Library World, 111(9/10), 391-398.

Gorman, P., Nelson, T., Glassman, A. (2004). The Millennial generation: a strategic opportunity. Organizational Analysis, 12(3), 255-340.

Henrie, K. and Taylor, C. (2009). Use of persuasion knowledge by the millennial generation. Young Consumers, 10(1), 71-81.

Hershatter, A. and Epstein, M. (2010). "Millennials and the world of work: an organization and management perspective." Journal of Business and Psychology, 25, 211-223.

Hira, N. A. (2007). Attracting the twenty something worker. Fortune, Mayo.

Howe, N., and Strauss, W. (2000). Millennials rising: The next great generation. New York: Vintage Books.

Jayson, Sharon. (2007 January 10). US A today, "Generation Y's goal? Wealth and fame fame", available at: http://usatoday.printthis.clickability.com/pt/cpt?actopm $=$ cpt\&title=generation $+Y$ (Accessed 27 December 2016).

Kirk, H. (2006). They are here to replace us: Recruiting and retaining Millennials. Journal of Financial Planning, November Supplement, 17.

Kohlberg, L. (1981), Essays on moral development, vol. I: The Philosophy of Moral Development, San Francisco, CA: Harper y Row.

Leandro, C., Giardini, S., Negreiros, J., Pedralho, M., \& Carvalhedo, R. (2013). Intervencao Breve an Preparacao para Aposentadoria. Revista Brasileira de Orientacao Profissional, 14(1), 99-110.

Leveson, L. \& Joiner, T. (2014). Exploring corporate social responsibility values of millennial jobseeking students. Education + Training, 56(1), 21-34.

Marciales-Vivas, G P; Cabra-Torres, F; (2009). Mitos, realidades y preguntas de investigación sobre los 'nativos digitales': Una revisión. Universitas Psychologica, 8, (323-338).

Marston, C. (2007). Motivating the "What's in it for me?" workforce: Manage across the generational divide and increase profits. Hoboken: Wiley.

Morrow, Paul. (2008). Helium, "Do we set up children for disappointment?, available at: http://www.helium.com/tm/288795/lived-happily-after-times (Accessed 27 December 2016).

Myers, K. and Sadaghiani, K. (2010). Millennials in the workplace: A communication perspective on Millennials' organizational relationships and performance. Journal of Business Psychology, 25, 225-238.

Nations, Harold L. (2007). Generation X \& Y powerpoint presentation, available at: http://www.howardnations.com/pdf-pt/GenXYW93.pps (Accessed 27 December 2016).

Nevbahar, E. (2015). Turnover intentions and work motivations of millennial employees in federal service. Public Personnel Management, 44(3), 401-423

Ng, E.S.W. and Schweitzer, L., Lyons, S. (2010). New generation, great expectations: A field study of the Millennial generation. Journal of Business Psychology, 25, 281-292

Noguera Fructuoso, I; (2015). How Milllennials are changing the way we learn: The state of the art of ICT integration in education. RIED.. Revista Iberoamericana de Educación a Distancia, 18 4565, available at: http://www.redalyc.org/articulo.oa?id=331433041003 (Accessed 27 December 2016).

Nolan, L. (2015). The roar of Millennials: Retaining top talent in the workplace. Journal of Leadership, Accountability and Ethics, 12(5), 69-75.

Pacheco, M., \& Castellá, J. (2012). Saliencia do papel de trabalhador, valores de trabalho e desenvolvimiento de carreira. Revista Brasileira de Orientacao Profissional, 13(1), 49-61. 
Peotter, E. (2015). One size doesn't fit all. The Journal for Quality and Participation, 38(3), 39-40.

Podsakoff, P. M.; Mackenzie, S. B.; Paine, J. B.; and Bachrach, D. G. (2000). Organizational citizenship behaviors: A critical review of the theoretical and empirical literature and suggestions for future research. Journal of Management, 26, 513-563.

Poleto, A., Lochins, C., \& Sirangelo, C. (2015). Career and family life: A study of bank executives. Revista Brasileira de Orientacao Profissional, 16(2), 185-195.

Rawlins, C., Indvik, J., Johnson, P. (2008). Understanding the new generation: what the millennial cohort absolutely, positively must have at work. Journal of Organizational Culture, Communications and Conflict, 12(2), 1-8

Rosa, E., Cunha, R., \& Souza, J. (2012). Diferentes Geracoes e Percepcoes sobre Carreiras Inteligentes e Crescimento Profissional nas Organizacoes. Revista Brasileira de Orientacao Profissional, 13(2), 197-207.

Smith, K. T. (2010). Work-life balance perspectives of marketing professionals in generation Y. Services Marketing Quarterly, 31(4), 434-447.

Smola, K.W., \& Sutton, C.D., (2002). Generational differences: revisiting generational work values for the new millennium. Journal of Organizational Behavior, 23, 363-382.

Thompson, N. W. (2011). Managing the Millennials: Employee retention strategies for generation Y. CMC Senior Theses. 240, available at: http://scholarship.claremont.edu/cmc_theses/240, (Accessed 27 December 2016)

Twenge, J.M., (2010). A review of empirical evidence on generational differences in work attitudes. Journal of Business and Psychology, 25(2), 201-210.

Villegas Portero, E; Labrador Ruiz de la Hermosa, E; (2016). Unir Gamificación y Experiencia de Usuario para mejorar la experiencia docente. RIED. Revista Iberoamericana de Educación a Distancia, 190 125-142, available at: http://www.redalyc.org/articulo.oa?id=331445859008, (Accessed 27 December 2016).

Vitorio, M., \& Lopes, E. (2012). Carreira e Familia: Divisao de tarefas domiciliares na vida de professoras universitárias. Revista Brasileira de Orientacao Profissional, 13(1), 103-110. 